\title{
Pandemic dehumanisation
}

\author{
IONA HEATH
}

\begin{abstract}
Richard Horton, The Covid19 catastrophe: What's gone wrong and how to stop it happening again, Polity Press, 2020. 133 pgs, \$13.99 (Kindle), \$16.59 (paperback), ISBN13: $9781509546466(\mathrm{pb})$
\end{abstract}

It is dangerous to embark on writing an account of an unfolding global catastrophe only a few short months after it began, but Richard Horton has never lacked courage. It is similarly hazardous to review the resulting book because of the unavoidable dangers of being unfair, as the passing months begin to allow the reviewer the considerable advantages of hindsight.

As the longstanding editor of the Lancet, with considerable expertise in global health and close links to the World Health Organisation, Horton is very well qualified to comment, if precipitately, on the Covid-19 disaster. He writes beautifully and he lays out, with exemplary clarity, the early science and epidemiology of the pandemic, and the varying contributions and obfuscations, successes and failures, of the different world leaders.

In his preface, he pleads that those who have died must not "become mere rates used to argue differences between nations" and emphasises the speed with which "the science and politics of COVID-19 became exercises in radical dehumanisation". Yet, sadly, much of the text that follows seems to demonstrate just how difficult it is to resist the pressure to focus on scientists, politicians and their manipulation of statistics, and how very easy it is to lose sight of the enormous amount of grief and misery being felt by individuals and families around the world. Perhaps Covid-19 has simply served to exaggerate the normal state of affairs which consistently dehumanises the most vulnerable. We must hope that the usefulness of the exaggeration is to prompt a reassessment of our priorities.

Author: Iona Heath (iona.heath22@yahoo.co.uk), Retired General Practitioner, London, UK; Past president of the Royal College of General Practitioners, UK.

To cite: Heath I. Pandemic dehumanisation. Indian J Med Ethics. 2021 JanMar; 6(1) NS: 79-80.DOI:10.20529/IJME.2020.123.

Published online on November 25, 2020.

Manuscript Editor: Sanjay A Pai.

(c) Indian Journal of Medical Ethics 2020
One of these future priorities should surely be intergenerational justice. Horton is already alive to the other pervasive issue of social justice manifested in the extraordinary way in which the virus has been able to critique the structures of societies across the world by systematically affecting and killing disadvantaged populations. However, the issues of intergenerational justice seem to have passed him by. Is it fair to lock children and young people out of school, training and university in order to try and contain an epidemic that seems to cause them serious illness very rarely indeed? These young people are the ones who will bear the brunt of the economic turmoil that will inevitably follow in the wake of the pandemic and which seems likely to affect their lives profoundly in terms of employment, working conditions, income, housing, cultural activities, political context and other aspects of a very uncertain future. With no school, the socioeconomic gap in school achievement has widened drastically and we do not know whether it can ever be closed. Children and young people isolated from their friends and their extended families have been exposed to increased rates of abuse, fear and mental distress, and again these experiences will play out over lifetimes. Yet, at the same time, their generation may just be being offered a once in a lifetime opportunity to work and vote for climate justice, a cleaner, healthier planet and a fairer, more inclusive economic system, less exploitative of both people and the environment.

It also seems that Horton was writing his book too soon to see and understand the futility of lockdowns that are not supported by effective testing, tracing and supported quarantine. It is in the magnitude of its failure in this regard that the United Kingdom (UK) really leads the world. The UK government under Boris Johnson has sought to continue to express its ideology of privatisation throughout the pandemic. As a direct result, the system of testing (which was started far too late) has been commissioned from private companies completely disconnected from either local government or the National Health Service. All existing public and environmental health expertise has been side-lined and the result has been chaos. When asked to quarantine because of established contact with a known case, people are offered no support and not only risk infecting other members of their households, but also often need to go out to buy essential supplies or even to continue working if they have no other source of income. It is more than telling that UK care homes that did not pay sick leave to their already extremely poorly paid care workers seem to have higher rates of both infection and death among their vulnerable elderly than those which did pay for their staff to 
stay off work if they became ill (1). No wonder the UK has sustained such a devastatingly high mortality rate from Covid19.

It has been striking that those global leaders who have come to power through promoting division and hate have also seemed to be the slowest in recognising the destructive power of the virus, claiming some sort of nationalist exceptionalism, resulting from a misplaced belief in the brilliance of their own leadership. Obvious examples include Johnson, Trump, Bolsonaro, and indeed, Narendra Modi. Presumably writing in April or May, Horton felt able to congratulate India on steering a safe course through the pandemic. Yet, at the time of writing this review in early October India was, for a time, recording the world's highest daily number of deaths (See: https:// www.ft.com/content/a2901ce8-5eb7-4633-b89c-

cbdf5b386938). The death rate per unit of population remains relatively low and much lower than that in the UK, the US, France and Spain, perhaps helped by India's much younger population. Nonetheless the neighbouring countries of Pakistan and Bangladesh appear to have significantly lower rates at the present time. The extent to which each of these leaders has continued to pursue a divisive ideology despite the pandemic is also remarkable: Johnson with his privatising and isolationist agenda; Trump using a disdain for facemasks to build conspiracy theories among his followers on the evangelical right; Bolsonaro doing absolutely nothing to protect the vulnerable indigenous peoples of the Amazon and allowing the burning and clearing of the rainforest to accelerate in the interests of big business; and Modi continuing to pursue and promote anti-Muslim policies and obliging millions of India's poorest to walk hundreds of kilometres back to their home villages.
Horton's book finishes with an optimistic chapter about the much-needed changes that must surely follow the pandemic. It is difficult to share his optimism while, six months after the publication of his book, the world is still floundering with many world leaders and policy experts showing no sign of making the necessary changes to their policy direction.

As the pandemic months roll by, an updated second edition of Horton's trenchant moral, social and political critique, built on his genuinely global perspective, is ever more urgently needed

Meanwhile, we must agree with Arundhati Roy when she lays out the stark choice:

Historically, pandemics have forced humans to break with the past and imagine their world anew. This one is no different. It is a portal, a gateway between one world and the next.

We can choose to walk through it, dragging the carcasses of our prejudice and hatred, our avarice, our data banks and dead ideas, our dead rivers and smoky skies behind us. Or we can walk through lightly, with little luggage, ready to imagine another world. And ready to fight for it. (2)

It is the young, across the world, who will decide which path is chosen.

\section{References}

1. Office for National Statistics, UK. Impact of coronavirus in care homes in England: 26 May to 19 June 2020 [cited 2020 Nov 22]. Available from: https://www.ons.gov.uk/peoplepopulationandcommunity/ healthandsocialcare/conditionsanddiseases/articles/ impactofcoronavirusincarehomesinenglandvivaldi/ 26mayto19june2020

2. Roy A. Arundhati Roy: The pandemic is a portal. Financial Times. 2020 Apr 3[cited 2020 Nov 22]. Available from: https://www.ft.com/content/ 10d8f5e8-74eb-11ea-95fe-fcd274e920ca

\section{IJME is indexed on Pubmed, Scopus \& TPI.}

Articles from IJME, as also from the journal's previous titles Medical Ethics (1993-5), and Issues in Medical Ethics (1996-2003) are indexed on Pubmed. 